MONIKA CHLIPAŁA

ORCID: 0000-0001-6216-2601

Uniwersytet Ekonomiczny w Krakowie

chlipalm@uek.krakow.pl

\title{
Przyczyny ustania związania przyrzeczeniem administracyjnym
}

\begin{abstract}
Abstrakt: Przedmiotem artykułu jest analiza regulacji prawnych odnoszących się do okoliczności skutkujących ustaniem związania przyrzeczeniem administracyjnym bez realizacji przedmiotu przyrzeczenia. W opracowaniu zaproponowano wyróżnienie następujących przyczyn ustania związania przyrzeczeniem administracyjnym: upływ okresu ważności przyrzeczenia, odmowa wydania aktu przyrzeczonego w okresie ważności przyrzeczenia, niespełnienie warunków określonych w promesie oraz cofnięcie przyrzeczenia. Obowiązujące akty prawne w obszarze omawianej problematyki nie zawierają jednolitego modelu normatywnego. Występujące unormowania cechuje zróżnicowanie i brak spójności. Zagadnienie ustania związania organu wydaną promesą bez wydania aktu przyrzeczonego jest ważne w szczególności z punktu widzenia funkcji gwarancyjnej przyrzeczenia administracyjnego oraz zasady budowy zaufania do administracji. Istotnym elementem konstrukcji normatywnej przyrzeczenia powinno być ograniczenie sytuacji prowadzących do ustania związania organu wydanym przyrzeczeniem bez realizacji jego przedmiotu.
\end{abstract}

Słowa kluczowe: przyrzeczenie administracyjne, promesa, prawne formy działania administracji, zaufanie do administracji.

\section{Wprowadzenie}

Podstawową funkcją przyrzeczenia administracyjnego (promesy) jest zapewnienie jednostki, że ponosząc określone nakłady (na przykład finansowe, organizacyjne), nie naraża się w przyszłości na działanie odmowne ze strony administracji. Przyrzeczenie administracyjne ${ }^{1}$, pozwalając przewidzieć działanie administracji,

${ }^{1}$ Ustawy materialne posługują się pojęciem ,promesa” bądź określeniem ,przyrzeczenie wydania określonego aktu”, traktując je jako równoznaczne. Termin „przyrzeczenie administracyjne” funkcjonuje przede wszystkim w doktrynie, gdzie albo jest utożsamiany z promesą (tak też przyjęto 
przyczynia się do budowy zaufania do administracji, które jest jedną z wartości w prawie administracyjnym. W doktrynie podkreśla się, że przyrzeczenie służy ograniczeniu występującej $\mathrm{w}$ prawie administracyjnym nieprzewidywalności treści legalnego działania administracji ${ }^{2}$.

Celem artykułu jest analiza unormowań prawnych dopuszczających ustanie związania organu wydanym przyrzeczeniem. Kwestia ta jest szczególnie istotna w sytuacji, kiedy ma miejsce ustanie związania organu przyrzeczeniem administracyjnym bez wydania aktu przyrzeczonego. Wystąpienie okoliczności ustania związania wydaną promesą wpływa nie tylko na organ, lecz także na adresata przyrzeczenia, który w takiej sytuacji traci status uprawnionego.

\section{Ustanie związania organu wydanym przyrzeczeniem administracyjnym}

O ustaniu związania organu wydanym przyrzeczeniem administracyjnym można mówić zarówno w razie jego realizacji, jak i jej braku. Jako typowe należy traktować przypadki, w których organ nie jest już związany treścią przyrzeczenia, gdyż czynność przyrzeczona została wykonana. Istotnym elementem konstrukcji normatywnej promesy jest ograniczenie sytuacji ustania związania organu bez realizacji przedmiotu przyrzeczenia, w tym najczęściej wydania aktu przyrzeczonego (decyzji administracyjnej). Wydanie promesy rodzi bowiem - co do zasady — po stronie organu stan samozwiązania się. Przypadki, w których nie dochodzi do wydania aktu przyrzeczonego, są sprzeczne z samą istotą tej formy działania; prowadzą do „uwolnienia się” organu od konieczności podjęcia określonej czynności.

W obowiązującym stanie prawnym przyczyny ustania związania wydaną promesą nie stanowią przedmiotu spójnej regulacji. Na podstawie analizy materiału normatywnego można zaproponować wyróżnienie następujących przyczyn ustania związania przyrzeczeniem administracyjnym: upływ okresu ważności przyrzeczenia, odmowa wydania aktu przyrzeczonego w okresie ważności przyrzeczenia, niespełnienie warunków określonych w promesie oraz cofnięcie przyrzeczenia.

\footnotetext{
w niniejszym artykule), albo traktowany jako określenie przedmiotowo szersze, obejmujące promesę oraz inne rodzaje przyrzeczeń. Zob. m.in. K. Wojtczak, M. Princ, Instytucja przyrzeczenia administracyjnego a zwiększenie zaufania do działalności władz publicznych, [w:] Sprawiedliwość i zaufanie do władz publicznych w prawie administracyjnym, red. M. Stahl, M. Kasiński, K. Wlaźlak, Warszawa 2015, s. 193; J. Zimmermann, Prawo administracyjne, Warszawa 2006, s. 353.

2 W. Jakimowicz, Kilka uwag o niepewności w prawie administracyjnym, [w:] Pewność sytuacji prawnej jednostki w prawie administracyjnym, red. A. Błaś, Warszawa 2012, s. 216.
} 


\section{Upływ okresu ważności przyrzeczenia administracyjnego}

W literaturze przedmiotu wskazuje się, że moc wiążąca przyrzeczeń jest ograniczona w czasie. Są one wydawane na wskazany okres, co oznacza, że upływ czasu, na jaki przyrzeczenie zostało wydane, prowadzi do jego bezskuteczności. Podjęcie przez organ działania w okresie ważności przyrzeczenia jest jednym z wymogów warunkujących jego realizację. Można go traktować jako cechę charakterystyczną przyrzeczenia, ponieważ wskazywanie w decyzjach administracyjnych okresu ich ważności nie jest regułą i wymaga podstawy prawnej upoważniającej organ do takiego działania.

W ustawach materialnoprawnych występują regulacje, zgodnie z którymi przyrzeczenie jest wydawane na czas określony. Powstaje pytanie o sposób unormowania „czasowego” charakteru przyrzeczenia w obowiązujących aktach prawnych. Można wskazać trzy sposoby ustalenia terminu ważności przyrzeczenia. Pierwszy polega na wskazaniu minimalnego okresu, na który przyrzeczenie może zostać wydane (przyrzeczenie wydania zezwolenia w zakresie zbiorowego zaopatrzenia w wodę lub zbiorowego odprowadzania ścieków zawiera ustalenie okresu ważności, który nie może być krótszy niż sześć miesięcy) ${ }^{3}$. Sposób drugi polega na zastosowaniu wariantu określającego maksymalny czas, na jaki przyrzeczenie może zostać wydane (przyrzeczenie zaszeregowania obiektu hotelarskiego do odpowiedniego rodzaju i kategorii jest wydawane na czas określony nie dłuższy niż dwa lata $)^{4}$. Sposób trzeci to sztywne wskazanie okresu ważności przyrzeczenia (przyrzeczenie wydania zezwolenia na nabycie nieruchomości przez cudzoziemca jest ważne rok od dnia wydania) ${ }^{5}$.

Upływ czasu powoduje wygaśnięcie przyrzeczenia, co prowadzi do jego bezskuteczności z mocy prawa. Obowiązujące regulacje materialnoprawne nie zawierają podstaw prawnych do stwierdzenia wygaśnięcia przyrzeczenia ze względu na upływ czasu, na jaki zostało ono wydane. Do stwierdzenia wygaśnięcia przyrzeczenia w drodze decyzji dochodzi w razie wydania aktu przyrzeczonego w okresie ważności przyrzeczenia. W takiej sytuacji właściwy organ, na podstawie art. 162 $\S 1$ pkt 1 k.p.a., stwierdza wygaśnięcie promesy, która stała się bezprzedmiotowa, w związku z tym, że zawarte w niej przyrzeczenie zostało zrealizowane.

W określonych przez ustawodawcę przypadkach niezłożenie wniosku o wydanie aktu przyrzeczonego w okresie ważności promesy prowadzi do dokonania przez właściwy organ czynności, którą można potraktować jako potwierdzenie

${ }^{3}$ Art. 17 c ust. 4 ustawy z dnia 7 czerwca 2001 roku o zbiorowym zaopatrzeniu w wodę i zbiorowym odprowadzaniu ścieków, tekst jedn. Dz.U. z 2017 r. poz. 328 ze zm.

${ }^{4}$ Art. 39a ust. 3 ustawy z dnia 29 sierpnia 1997 roku o usługach hotelarskich oraz usługach pilotów wycieczek i przewodników turystycznych, tekst jedn. Dz.U. z 2019 r. poz. 238.

5 Art. 3 d ust. 2 ustawy z dnia 24 marca 1920 roku o nabywaniu nieruchomości przez cudzoziemców, tekst jedn. Dz.U. z 2017 r. poz. 2278. 
bezskuteczności promesy. Sytuacja taka dotyczy przyrzeczenia zaszeregowania obiektu hotelarskiego do odpowiedniego rodzaju i kategorii. Jeżeli przedsiębiorca, któremu promesa została udzielona, nie złoży przed upływem terminu jej ważności wniosku o zaszeregowanie obiektu do odpowiedniego rodzaju i kategorii, marszałek województwa z urzędu wykreśla obiekt z wykazu promes, o czym zawiadamia przedsiębiorcę 6 .

Biorąc pod uwagę skutek, jaki wywołuje upływ terminu ważności przyrzeczenia, powstaje pytanie o możliwość przedłużenia tego okresu. W doktrynie wyrażono pogląd przyjmujący dopuszczalność przedłużenia okresu ważności promesy na wykonywanie koncesjonowanej działalności gospodarczej - obowiązujące przepisy nie formułują bowiem takiego zakazu ${ }^{7}$. Wówczas wyłączenie przedłużenia terminu przyrzeczenia miałoby miejsce w sytuacjach, w których ustawodawca expressis verbis sformułował taki zakaz. Z punktu widzenia adresata przyrzeczenia, który z różnych przyczyn może nie spełnić sformułowanych w nim warunków, stanowisko opowiadające się za przyjęciem generalnej klauzuli o możliwości przedłużenia okresu ważności przyrzeczenia jest niewątpliwie rozwiązaniem korzystniejszym. Jest to dopuszczalne w odniesieniu do promes będących decyzjami administracyjnymi. Znajduje w tym wypadku zastosowanie art. 155 k.p.a., na podstawie którego każda decyzja administracyjna, na mocy której strona nabyła prawo, może zostać za jej zgodą zmieniona, a zmiana może dotyczyć także wydłużenia okresu obowiązywania promesy ${ }^{8}$. Potwierdza to także praktyka. Na podstawie tej regulacji wydawane są decyzje na przykład przez Prezesa Urzędu Regulacji Energetyki w sprawie zmiany promesy koncesji na obrót energią elektryczną w przedmiocie przedłużenia ważności promesy koncesji na określony czas.

W odniesieniu do przyrzeczeń niebędących decyzjami administracyjnymi dopuszczalność ich przedłużenia wymaga szczegółowej podstawy prawnej. Dotyczy to na przykład przyrzeczenia udzielenia dofinansowania przedsięwzięć z zakresu produkcji filmów, które może zostać przedłużone, jednak nie więcej niż o kolejne sześć miesięcy ${ }^{9}$.

W obowiązujących regulacjach prawnych przedmiotem przyrzeczenia administracyjnego jest zobowiązanie się organu do określonego działania. Nie jest

$6 \S 18$ ust. 3 pkt 1 rozporządzenia Ministra Gospodarki i Pracy z dnia 19 sierpnia 2004 roku w sprawie obiektów hotelarskich i innych obiektów, w których są świadczone usługi hotelarskie, tekst jedn. Dz.U. z 2017 r. poz. 2166.

${ }^{7}$ L. Bielecki, P. Ruczkowski, Koncesja w prawie lotniczym. Zagadnienia administracyjnoprawne, Kielce 2010, s. 157.

8 Rozdziat VII, [w:] Prawo energetyczne, t. 2. Komentarz do art. 12-72, red. Z. Muras, M. Swora, LEX 2016.

$9 \S 14$ ust. 2 Rozporządzenia Ministra Kultury z dnia 27 października 2005 roku w sprawie udzielenia przez Polski Instytut Sztuki Filmowej dofinansowania przedsięwzięć z zakresu kinematografii, Dz.U. z 2005 r. Nr 219, poz. 1870. 
natomiast wykluczone, przynajmniej w ujęciu teoretycznym, zobowiązanie się organu do zaniechania. W takiej sytuacji trzeba zwrócić uwagę, że inna jest rola terminu. W przypadku zobowiązania się organu do niepodejmowania działania upływ czasu, na jaki przyrzeczenie zostało wydane, rodzi konsekwencje pozytywne dla adresata $-\mathrm{z}$ mocy prawa powstają określone skutki prawne.

\section{Odmowa wydania aktu przyrzeczonego w okresie ważności przyrzeczenia}

Przyrzeczenie administracyjne ma na celu zapewnienie jednostki, że w okresie jego ważności wskazana $\mathrm{w}$ nim czynność zostanie podjęta. Normatywnym wyrazem tej funkcji są regulacje, zgodnie z którymi w okresie ważności promesy nie można odmówić wydania aktu przyrzeczonego, chyba że wystąpią enumeratywnie określone okoliczności prowadzące do ustania związania organu wydanym przyrzeczeniem. Tego typu rozwiązanie występuje na przykład przy promesie na wykonywanie koncesjonowanej działalności gospodarczej ${ }^{10}$, promesie wydania zezwolenia na nabycie nieruchomości przez cudzoziemca ${ }^{11}$, promesie zezwolenia na utworzenie otwartego funduszu emerytalnego ${ }^{12}$. Natomiast omawiane unormowanie nie zostało przyjęte $\mathrm{w}$ odniesieniu do na przykład przyrzeczenia wydania zezwolenia w zakresie zbiorowego zaopatrzenia w wodę lub zbiorowego odprowadzania ścieków. W ustawie o zbiorowym zaopatrzeniu w wodę i zbiorowym odprowadzaniu ścieków przyjęto, że w postępowaniu o udzielenie promesy stosuje się przepisy dotyczące udzielania zezwolenia, które określają przesłanki odmowy udzielenia zezwolenia. Oznacza to, że unormowane są wyłącznie przesłanki odmowy wydania promesy ${ }^{13}$.

Odmowa wydania aktu, mimo ważności przyrzeczenia, może mieć miejsce w razie wystąpienia unormowanych expressis verbis przesłanek, które najczęściej obejmują: zmianę stanu prawnego, zmianę stanu faktycznego, zmianę danych zawartych we wniosku o udzielenie promesy, niespełnienie warunków określonych $\mathrm{w}$ promesie (ta przesłanka jest przedmiotem odrębnego omówienia w dalszej części artykułu), zagrożenie obronności lub bezpieczeństwa państwa lub innego ważnego interesu publicznego oraz zagrożenie dóbr osobistych obywateli ${ }^{14}$.

10 Art. 43 ust. 4 ustawy z dnia 10 kwietnia 1997 roku — Prawo energetyczne, tekst jedn. Dz.U. z 2019 r. poz. 755 ze zm.

11 Art. 3d ust. 4 ustawy z dnia 24 marca 1920 roku o nabywaniu nieruchomości przez cudzoziemców.

12 Art. 56 ust. 3 ustawy z dnia 28 sierpnia 1997 roku o organizacji i funkcjonowaniu funduszy emerytalnych, tekst jedn. Dz.U. z 2018 r. poz. 1906 ze zm.

13 Art. $17 \mathrm{c}$ ust. $3 \mathrm{w}$ zw. z art. $17 \mathrm{~b}$ ustawy o zbiorowym zaopatrzeniu w wodę i zbiorowym odprowadzaniu ścieków.

14 Art. 43 ust. 4 ustawy z dnia 10 kwietnia 1997 roku — Prawo energetyczne, zgodnie z którym „w okresie ważności promesy nie można odmówić udzielenia koncesji na działalność określoną 
W literaturze wskazuje się, że zmiana stanu faktycznego „może dotyczyć zarówno okoliczności odnoszących się do samego przedsiębiorcy, jak i do zamierzonej działalności tego podmiotu, na przykład jej rodzaju lub rozmiarów"15. Zaznacza się również, że

nie każda zmiana okoliczności faktycznych oznacza zwolnienie organu koncesyjnego z obowiązku wydania koncesji, ale taki skutek powinny pociągać za sobą jedynie zmiany istotne, mające w świetle obowiązujących przepisów prawa wpływ na treść decyzji. Natomiast nie powinny być brane pod uwagę - jako przesłanka odmowy udzielenia koncesji — zmiany nieistotne, takie na przykład jak zmiana adresu przedsiębiorcy ${ }^{16}$.

Przesłanką odmowy wykonania przyrzeczenia jest zmiana stanu prawnego, co można rozumieć zarówno

jako zmianę sytuacji prawnej przedsiębiorcy w porównaniu z tą, jaka występowała podczas przyznawania promesy (na przykład zmiana charakteru prawnego przedsiębiorcy w wyniku jego przekształcenia) oraz jako zmianę przepisów prawa (ustaw i aktów wykonawczych do ustaw), stanowiących podstawę prawną decyzji o udzieleniu koncesji ${ }^{17}$.

Największe wątpliwości, z punktu widzenia gwarancyjnej funkcji przyrzeczenia, może wywoływać przesłanka odmowy realizacji przyrzeczenia ze względu na zagrożenie obronności lub bezpieczeństwa państwa lub innego ważnego interesu publicznego. Istotne jest unikanie sytuacji, gdy wydanie aktu przyrzeczonego nie jest zależne od spełnienia przez jednostkę zawartych w przyrzeczeniu warunków, ale od okoliczności uznanych przez organ za uniemożliwiające podjęcie rozstrzygnięcia finalnego.

Normowane w aktach prawnych przesłanki odmowy wydania aktu przyrzeczonego tworzą katalog zamknięty, ale — odwołując się do zaproponowanej wyżej klasyfikacji - nie stanowią jedynych przypadków prowadzących do ustania związania organu wydanym przyrzeczeniem administracyjnym. Analizując obowiązujące przyczyny, których wystąpienie prowadzi do odmowy udzielenia koncesji czy zezwolenia mimo ważności promesy, można przyjąć, że niedopuszczenie do ich powstania w przeważającej mierze zależy od adresata promesy. Niemniej jednoznaczna ocena nie zawsze będzie możliwa, na przykład odmowa udzielenia

w promesie, chyba że uległ zmianie stan faktyczny lub prawny podany we wniosku o wydanie promesy". Art. 3d ust. 4 ustawy z dnia 24 marca 1920 roku o nabywaniu nieruchomości przez cudzoziemców, zgodnie z którym „w okresie ważności promesy nie można odmówić wydania zezwolenia, chyba że uległ zmianie stan faktyczny istotny dla rozstrzygnięcia sprawy”. Art. 37an ust. 4. ustawy Prawo farmaceutyczne „w okresie ważności promesy nie można odmówić udzielenia zezwolenia na wykonywanie działalności gospodarczej określonej w promesie, chyba że: 1) uległy zmianie dane zawarte we wniosku o udzielenie promesy albo 2) wnioskodawca nie spełnił wszystkich warunków podanych w promesie, albo 3) wnioskodawca nie spełnia warunków wykonywania działalności objętej zezwoleniem, albo 4) jest to uzasadnione zagrożeniem obronności lub bezpieczeństwa państwa lub innego ważnego interesu publicznego".
15 Rozdziat VII...
16 Ibidem.
17 Ibidem. 
koncesji ze względu na zagrożenie obronności lub bezpieczeństwa państwa lub obywateli może być spowodowana okolicznościami obiektywnymi, nie zawsze pozostającymi w ścisłym związku z zachowaniem adresata przyrzeczenia.

Brzmienie regulacji prawnych dotyczących odmowy wydania aktu przyrzeczonego wskazuje, że występująca w tym obszarze kompetencja organu ma charakter swobodny. W tych przypadkach ustawodawca przyjmuje, że w okresie ważności promesy nie można odmówić wydania aktu przyrzeczonego, chyba że wystąpi któraś ze wskazanych sytuacji, a jeżeli tak, to organ nie jest zobowiązany do odmowy, ale może udzielić koncesji/zezwolenia.

Odmowa realizacji przyrzeczenia może mieć różny charakter prawny, który niekoniecznie musi być tożsamy z charakterem przyrzeczenia. W przypadkach, w których przyrzeczenie jest decyzją administracyjną, także odmowa wydania aktu przyrzeczonego ma formę decyzji. Natomiast w wypadku przyrzeczeń dokonywanych w innych formach nie jest wykluczone, aby odmowa miała również formę aktu administracyjnego, aczkolwiek wymaga to wyraźnego unormowania. System prawny zna rozwiązania, zgodnie z którymi dokonanie czynności pozytywnej, na przykład wpisu do rejestru, ma formę czynności faktycznej, a odmowa wpisu następuje w drodze decyzji administracyjnej. Wobec braku tego rodzaju wypowiedzi ustawodawcy należy przyjąć, że odmowa wydania przyrzeczenia następuje przez poinformowanie o niemożliwości jego realizacji. Dotyczy to przyrzeczenia udzielenia dofinansowania przedsięwzięć z zakresu kinematografii. Realizacja przyrzeczenia, czyli zawarcie umowy o dofinansowanie, jest uzależniona od spełnienia warunków określonych $\mathrm{w}$ promesie, zatem $\mathrm{w}$ razie ich niespełnienia nie jest ona możliwa, o czym podmiot udzielający powinien poinformować adresata.

W obszarze omawianej problematyki warto jeszcze zwrócić uwagę na zmianę treści przyrzeczenia w trakcie jego ważności. Sytuacja taka nie prowadzi do ustania związania organu wydanym przyrzeczeniem, ale zmienia jego zakres. Nie ma w obowiązujących aktach normatywnych regulacji wprost dopuszczających tego typu działanie. Na temat dopuszczalności zmiany promesy w trakcie jej ważności pośrednio wypowiada się ustawa Prawo energetyczne, wskazując, że za udzielenie promesy lub jej zmianę pobiera się opłatę skarbową ${ }^{18}$. W opracowaniach dotyczących tej ustawy podnosi się, że przedsiębiorca może złożyć wniosek o zmianę promesy koncesji, a zmiana może dotyczyć sytuacji formalnoprawnej przedsiębiorcy (na przykład zmiana nazwy, zmiana adresu siedziby) oraz zakresu działalności (na przykład zamiar rozszerzenia lub zawężenia zakresu promesy koncesji). W takim wypadku pozostaje do rozważenia charakter zmian — należy mieć na uwadze, że zmiana stanu faktycznego jest podstawą odmowy wydania koncesji, a nie zmiany promesy. Dopuszczalność zmiany promesy powinna zatem zostać ograniczona tylko do zmian nieistotnych, które nie uzasadniają odmowy realizacji przyrzeczenia.

18 Art. 43aa ustawy Prawo energetyczne. 


\section{Niespełnienie warunków określonych w przyrzeczeniu administracyjnym}

W doktrynie określa się przyrzeczenie jako czynność prawną uwarunkowaną, ponieważ załatwienie sprawy przez organ administracji, zgodnie z treścią przyrzeczenia, jest możliwe „najwcześniej z chwilą spełnienia się warunku będącego wyrazem istnienia przeszkody w bezpośrednim załatwieniu żądania obywatela" ${ }^{19}$.

W prawie administracyjnym pojęcie warunku nie jest jednoznaczne. Pierwszym kontekstem występowania warunku jest traktowanie go jako elementu dodatkowego (akcesoryjnego) decyzji administracyjnej, którego dopuszczalność zamieszczenia wynika z przepisów prawa materialnego. Zawarcie warunku jest uzależnione od szczegółowego upoważnienia ustawowego, ale o dodaniu do aktu administracyjnego tego typu oświadczenia woli decyduje organ, a nie ustawodawca, co ma miejsce przy tak zwanych warunkach prawnych. Istota warunku w przedstawianym znaczeniu sprowadza się do możliwości uzależnienia wywołania określonych skutków prawnych (na przykład wygaśnięcia obowiązku czy uprawnienia ustalonego aktem) od zdarzenia przyszłego i niepewnego w tym sensie, że nie można w sposób stanowczy przesądzić o tym, kiedy i czy w ogóle takie zdarzenie wystąpi, czy też zostanie zrealizowane ${ }^{20}$. Zdarzeniem przyszłym i niepewnym może być zachowanie się samego adresata aktu, zachowanie się osób trzecich, w tym organów, bądź też spełnienie się zdarzeń losowych, niezależnych od człowieka $^{21}$. Wraz ze ziszczeniem się zdarzenia przyszłego i niepewnego z mocy prawa wywołany zostaje przewidziany danym aktem skutek prawny.

Po drugie, warto zwrócić uwagę na warunek rozumiany jako tak zwany warunek prawny będący ustawowymi wymogi wydania aktu lub podjęcia czynności, które nie mogą odnosić się do zdarzeń przyszłych i niepewnych ${ }^{22}$. K. Ziemski wskazuje, że nie mamy do czynienia z warunkiem rozumianym jako element akcesoryjny aktu w sytuacji, „kiedy prawodawca uzależnia wydanie aktu administracyjnego od spełnienia się pewnych okoliczności, zdarzeń, zachowań czy właściwości po stronie adresata". W tym ujęciu określenie warunków nie należy do organu, a ocena ich wystąpienia jest jego obowiązkiem i musi poprzedzać podjęcie rozstrzygnięcia ${ }^{23}$.

19 W. Taras, Przyrzeczenie administracyjne, [w:] Polska lat 90-tych. Przemiany państwa i prawa, red. M. Mozgawa et al., Lublin 1997, s. 146.

${ }^{20}$ K.M. Ziemski, Formy prawne w sferze działań zewnętrznych administracji publicznej, [w:] System Prawa Administracyjnego, t. 5. Prawne formy działania administracji, red. J. Boć, M. Stahl, K.M. Ziemski, Warszawa 2013, s. 204. T. Woś wskazuje, że ,jako warunek w prawie administracyjnym może być traktowane wyłącznie takie oświadczenie woli organu administracyjnego — dodane do decyzji jak jej postanowienie uboczne - ale pozostające z nią w ścisłym związku, na podstawie którego moc wiążąca w czasie decyzji (rozpoczęcie lub ustanie jej obowiązywania) zostaje uzależniona od zdarzenia przyszłego, niepewnego" - idem, Termin, warunek i zlecenie w prawie administracyjnym, „Państwo i Prawo” 1994, nr 6, s. 28.

21 K.M. Ziemski, op. cit., s. 204.

22 Ibidem.

23 T. Woś, op. cit., s. 27-28.

Prawo 329, 2020

(C) for this edition by CNS 
Na podstawie obowiązujących aktów prawnych można wyszczególnić trzy podejścia legislacyjne dotyczące warunków w przyrzeczeniu. Pierwsze polega na zobowiązaniu organu do zamieszczenia warunków, drugie charakteryzuje się fakultatywnością w tym zakresie, trzecie - brakiem wypowiedzi ustawodawcy w kwestii zamieszczenia warunków w przyrzeczeniu.

$\mathrm{W}$ odniesieniu do przyrzeczeń, w których zamieszczenie warunków jest obligatoryjne, jednym z występujących rozwiązań jest wskazanie, że organ wydający przyrzeczenie ustala $\mathrm{w}$ nim warunki niezbędne dla wydania aktu przyrzeczonego, których treść wynika z regulacji ustawowych, a nie pochodzi od organu. Takie ujęcie odpowiada warunkowi rozumianemu jako warunek prawny. Ustawa o ochronie osób i mienia przyjmuje, że w promesie uzależnia się udzielenie koncesji od spełnienia warunków wykonywania działalności gospodarczej wymagającej uzyskania koncesji ${ }^{24}$, które są określone w ustawie. Modyfikacją tego sposobu ustalania warunku jest upoważnienie organu do określenia dodatkowych warunków. Zgodnie z powołaną ustawą koncesja może zawierać szczególne warunki wykonywania działalności gospodarczej w zakresie ochrony osób i mienia określone przez organ. Regulacja ta znajduje zastosowanie także do przyrzeczenia - ustawa odsyła bowiem do stosowania przepisów dotyczących koncesji ${ }^{25}$. Wspomniane szczególne warunki wykonywania działalności gospodarczej cechuje fakultatywny charakter oraz wpływ organu na ich treść — odpowiadają zatem warunkowi w ścisłym znaczeniu, ale nie mogą być traktowane jako element akcesoryjny aktu. Stanowią jedynie uzupełnienie warunków prawnych, a ich ziszczenie się nie prowadzi do powstania skutków prawnych z mocy prawa.

Kolejnym przykładem przyrzeczenia, w którym mamy do czynienia z warunkiem prawnym, jest promesa zezwolenia na szkolenie lotnicze, której wydanie jest możliwe, jeżeli wnioskodawca spełnia warunki rozumiane jako wymogi ustawowe niezbędne do uzyskania zezwolenia na szkolenie lotnicze w Rzeczypospolitej Polskiej, poza przesłanką, jaką jest posiadanie wizy lub zezwolenia ${ }^{26}$.

Pozostając przy regulacjach wprowadzających obowiązek ustalenia warunku w przyrzeczeniu, występują również takie, w których ustawodawca nie normuje zakresu przedmiotowego warunków, ale w razie wydania przyrzeczenia ich wprowadzenie jest obligatoryjne. Organ ma zatem wpływ na treść warunku, lecz nie dysponuje uznaniem w kwestii jego zamieszczenia. Takie rozwiązanie dotyczy przyrzeczenia udzielenia dofinansowania przedsięwzięć z zakresu produkcji filmów ${ }^{27}$.

24 Art. 17c ust. 1 ustawy z dnia 22 sierpnia 1997 roku o ochronie osób i mienia, tekst jedn. Dz.U. z 2018 r. poz. 2142 ze zm.

25 Art. 18 ust. 2 w zw. z art. 17 c ust. 2 ustawy o ochronie osób i mienia.

$26 \S 7$ rozporządzenia Ministra Infrastruktury z dnia 7 sierpnia 2003 roku w sprawie szkolenia lotniczego oraz uzyskiwania licencji przez cudzoziemców, Dz.U. 2003 r. Nr 150, poz. 1524.

27 Zgodnie z $§ 14$ ust. 3 rozporządzenia Ministra Kultury z dnia 27 października 2005 roku w sprawie udzielenia przez Polski Instytut Sztuki Filmowej dofinansowania przedsięwzięć z zakre- 
Drugim sposobem normowania warunku w przyrzeczeniu jest pozostawiony organowi wybór dotyczący ich zamieszczenia. Natomiast w kwestii wpływu organu na treść warunku występują zarówno rozwiązania przyjmujące, że pokrywa się ona z wymogami ustawowymi bądź też jej ustalenie należy do organu. Do przyrzeczeń, w których zamieszczenie warunków jest fakultatywne, należą: przyrzeczenie wydania zezwolenia w zakresie zbiorowego zaopatrzenia w wodę lub zbiorowego odprowadzania ścieków oraz przyrzeczenie wydania zezwolenia na nabycie nieruchomości przez cudzoziemca. W promesie zezwolenia $\mathrm{w}$ zakresie zbiorowego zaopatrzenia w wodę i zbiorowego odprowadzania ścieków ustawa wprowadza możliwość uzależnienia udzielenia zezwolenia od spełnienia warunków wykonywania działalności objętej zezwoleniem ${ }^{28}$. Warunkami tymi są wymogi ustawowe dotyczące prowadzenia danej działalności. Natomiast w promesie zezwolenia na nabycie nieruchomości przez cudzoziemca organ ustala treść warunków, które ustawa określa jako specjalne warunki, od których spełnienia będzie uzależnione wydanie zezwolenia ${ }^{29}$.

$\mathrm{W}$ analizowanych aktach normatywnych występują także przyrzeczenia, w odniesieniu do których ustawodawca nie wskazuje ani na obowiązek, ani na możliwość zamieszczenia w nich warunku. Przykładowo organ nie jest upoważniony do zamieszczenia warunku w promesie zezwolenia na utworzenie otwartego funduszu emerytalnego. Akt ten jest wydawany, jeżeli nie zachodzą przesłanki do odmowy wydania (które są unormowane w odniesieniu do odmowy wydania zezwolenia). Nasuwa się pytanie, czy organ może sam uwarunkować przyrzeczenie. Uzasadnienia dopuszczalności takiego działania można poszukiwać w tym, że $\mathrm{z}$ istoty promesy wynika możliwość zamieszczenia $\mathrm{w}$ niej warunku, jeżeli w ocenie organu jest to niezbędne do realizacji celu przyrzeczenia, czyli wydania aktu finalnego.

Występowanie warunku w przyrzeczeniu administracyjnym jest pochodną jego zawieszającego charakteru będącego cechą każdego przyrzeczenia. Obowiązujący materiał normatywny wprowadza w tym zakresie znaczne zróżnicowanie. Warunek jest ujmowany jako obligatoryjny albo fakultatywny element przyrzeczenia. Organ jest pozbawiony wpływu na treść warunków albo ma taką możliwość. Przyrzeczenie administracyjne jest czynnością uwarunkowaną, ale pojęcie warunku nie jest rozumiane jednolicie. Część regulacji prawnych dotyczących przyrzeczenia traktuje wa-

su kinematografii dyrektor zawiera umowę o dofinansowanie po spełnieniu przez wnioskodawcę warunków promesy.

${ }^{28}$ Art $17 \mathrm{c}$ ust. 2 ustawy o zbiorowym zaopatrzeniu w wodę i zbiorowym odprowadzaniu ścieków stanowi, że w promesie wójt (burmistrz, prezydent miasta) może uzależnić udzielenie zezwolenia od spełnienia warunków wykonywania działalności objętej zezwoleniem.

${ }^{29}$ Zgodnie z art. 3d ust. $1 \mathrm{w}$ zw. z art. 2 ust. 2 ustawy o nabywaniu nieruchomości przez cudzoziemców w przyrzeczeniu wydania zezwolenia na nabycie nieruchomości przez cudzoziemca minister właściwy do spraw wewnętrznych może określić warunki, od których spełnienia uzależnione jest wydanie zezwolenia. 
runek jako ustawową przesłankę ważności wydania przyrzeczenia, czyli tak zwany warunek prawny, który - w zależności od sposobu unormowania - może mieć charakter obligatoryjny albo fakultatywny. W obydwu przypadkach, co jest cechą tak ujmowanego warunku, organ nie ma wpływu na jego treść.

Brak realizacji warunków przyrzeczenia w określonym w nim terminie stanowi przesłankę ustania związania organu, którą można określić jako zależną od jednostki w tym znaczeniu, że właśnie adresat przyrzeczenia ma wpływ na to, aby termin nie upłynął bezskutecznie. Oczywiście powody niespełnienia warunków określonych w przyrzeczeniu w ustalonym okresie mogą być bardzo różne i nie zawsze uzależnione od woli jednostki. Niespełnienie warunków prowadzi do decyzji w sprawie odmowy wydania koncesji/zezwolenia.

\section{Cofnięcie przyrzeczenia administracyjnego}

Niezwiązanie organu wydanym przyrzeczeniem ma miejsce także w razie jego cofnięcia. W regulacjach prawnych nie ma bezpośredniego wskazania, że może mieć miejsce cofnięcie przyrzeczenia. Ta forma dotyczy koncesji i zezwoleń, w odniesieniu do których ustawodawca normuje przypadki obligatoryjnego oraz fakultatywnego cofnięcia tego aktu uprawniającego. W doktrynie nie ma niestety jednolitego stanowiska. Z jednej strony podnosi się, że „nie ma racjonalnych przesłanek, by cofać promesę, gdyż w sytuacji, kiedy zmienia się stan faktyczny bądź prawny, istnieje możliwość odmowy udzielenia koncesji” ${ }^{30}$. Z drugiej natomiast wskazuje się na możliwość cofnięcia promesy, która może mieć miejsce tylko w okresie jej ważności oraz z tych samych powodów co cofnięcie konce$\mathrm{sji}^{31}$. Należy zaznaczyć, że katalog przesłanek cofnięcia koncesji (i odpowiednio promesy) różni się od przesłanek odmowy wydania koncesji. W związku z tym, że upoważnienie do cofnięcia koncesji czy zezwolenia jest konstruowane jako uprawnienie bądź obowiązek organu, także w odniesieniu do promesy, wystąpienie określonej przesłanki nie zawsze będzie prowadzić do obowiązku wydania decyzji w sprawie jej cofnięcia, a tym samym ustania związania przyrzeczeniem administracyjnym.

W związku z tym, że przyrzeczenie organu jest najczęściej decyzją administracyjną, poza przypadkami, kiedy nie dochodzi do jego realizacji unormowanymi w ustawach materialnych, skutek taki może mieć miejsce w razie zastosowania regulacji procesowych, w tym nadzwyczajnych środków wzruszania decyzji. Sytuacje te prowadzą także do ustania związania organu wydanym przyrzeczeniem.

30 A. Trela, Nowe zasady koncesjonowania działalności gospodarczej, „Ruch Prawniczy, Ekonomiczny i Socjologiczny" 2002, z. 2, s. 101.

31 C. Kosikowski, Ustawa o swobodzie działalności gospodarczej. Komentarz, Warszawa 2013, s. 277. Zob. także M. Czarnecka, T. Ogłódek, Prawo energetyczne. Komentarz, Warszawa 2012. 


\section{Podsumowanie}

Na podstawie obowiązującego materiału normatywnego można sformułować kilka wniosków dotyczących problematyki ustania związania organu wydanym przyrzeczeniem.

Przesłanki skutkujące niewydaniem aktu przyrzeczonego nie stanowią przedmiotu spójnej regulacji. Są akty prawne, w których nie występują unormowania w zakresie dopuszczalności ustania związania przyrzeczeniem. Z pewnością nie można mówić o występowaniu jednego modelu normatywnego w tym obszarze, co jest pochodną niewystarczającego uregulowania przyrzeczenia administracyjnego w polskim systemie prawnym.

Nie zawsze wystąpienie przyczyny ustania zawiązania przyrzeczeniem prowadzi do jego upadku. Przyczyny ustania związania prowadzą (na przykład upływ terminu ważności przyrzeczenia) albo mogą prowadzić (na przykład odmowa wydania koncesji/zezwolenia; cofnięcie promesy) do tego skutku.

Występuje zróżnicowanie w kwestii ,potwierdzania” ustania związania przyrzeczeniem, na przykład decyzja administracyjna w sprawie odmowy wydania promesy, czynność faktyczna - wykreślenie $\mathrm{z}$ wykazu promes.

Brakuje ujednolicenia w zakresie unormowania warunkowego charakteru przyrzeczenia administracyjnego. Warunek jest ujmowany jako obligatoryjny albo fakultatywny element przyrzeczenia. Organ jest pozbawiony wpływu na treść warunków albo ma taką możliwość.

Postulatem de lege ferenda, który w świetle przeprowadzonej analizy wydaje się oczywisty, jest potrzeba opracowania spójnych regulacji prawnych dotyczących ustania związania organu wydanym przyrzeczeniem. Tego typu rozwiązania, wobec braku przepisów ogólnych prawa administracyjnego, powinny się znaleźć $\mathrm{w}$ aktach materialnych normujących dany rodzaj promesy.

\section{Bibliografia}

Bielecki L., Ruczkowski P., Koncesja w prawie lotniczym. Zagadnienia administracyjnoprawne, Kielce 2010.

Czarnecka M., Ogłódek T., Prawo energetyczne. Komentarz, Warszawa 2012.

Jakimowicz W., Kilka uwag o niepewności w prawie administracyjnym, [w:] Pewność sytuacji prawnej jednostki w prawie administracyjnym, red. A. Błaś, Warszawa 2012.

Kosikowski C., Ustawa o swobodzie działalności gospodarczej. Komentarz, Warszawa 2013.

Prawo energetyczne, t. 2. Komentarz do art. 12-72, red. Z. Muras, M. Swora, LEX 2016.

Taras W., Przyrzeczenie administracyjne, [w:] Polska lat 90-tych. Przemiany państwa i prawa, red. M. Mozgawa et al., Lublin 1997.

Trela A., Nowe zasady koncesjonowania działalności gospodarczej, „Ruch Prawniczy, Ekonomiczny i Socjologiczny" 2002, z. 2. 
Wojtczak K., Princ M., Instytucja przyrzeczenia administracyjnego a zwiększenie zaufania do dziatalności władz publicznych, [w:] Sprawiedliwość i zaufanie do władz publicznych w prawie administracyjnym, red. M. Stahl, M. Kasiński, K. Wlaźlak, Warszawa 2015.

Woś T., Termin, warunek i zlecenie w prawie administracyjnym, „Państwo i Prawo” 1994, nr 6.

Ziemski K.M., [w:] System Prawa Administracyjnego, t. 5. Prawne formy działania administracji, red. J. Boć, M. Stahl, K.M. Ziemski, Warszawa 2013.

Zimmermann J., Prawo administracyjne, Warszawa 2006.

\title{
Legal regulations concerning termination of administrative promise
}

\begin{abstract}
Summary
The subject of the article is the analysis of legal regulations relating to circumstances resulting in the termination of administrative promise without implementation of the subject of the promise. The article proposes to distinguish the following reasons for termination of administrative promise: expiry of the period of validity of the promise, refusal to issue the promised act during the period of validity of the promise, failure to meet the conditions set out in the promise, and withdrawal of the promise. The applicable legal acts in the area of the discussed issues do not contain a uniform normative model. The issue of termination of binding of the body by a promise issued without the issue of a promised act is important, in particular from the point of view of the guarantee function of the administrative promise and the principle of building trust in the administration. An important element of the normative construction of a promise should be the limitation of situations leading to cessation of binding of the body by the promise issued without the implementation of its subject.
\end{abstract}

Keywords: trust in public administration, administrative promise, legal forms of administrative action. 